\title{
Beyond task performance: the concept of organizational citizenship performance
}

\author{
Dan Ispas ${ }^{1}$ \\ Walter C. Borman \\ University of South Florida
}

\begin{abstract}
In this paper, we describe the construct of citizenship performance and briefly review some of the industrial and organizational psychology research on organizational citizenship. We discuss the history, the dimensionality, the antecedents, consequences and implications for practice, and also provide a critical analysis. The conclusions of this review are that citizenship performance is important for contemporary organizations and contemporary trends suggest it will continue to be important in the future. We encourage further research in the area of citizenship performance in other cultures beyond the US.
\end{abstract}

Key words: citizenship performance, organizational citizenship behaviors, job performance, industrialorganizational psychology.

\begin{abstract}
Rezumat
În cadrul acestei lucrări ne propunem să realizăm o descriere a constructului de performanță contextuală şi să trecem în revistă pe scurt câteva dintre cercetările din psihologia industrială şi organizațională asupra comportamentului cetățenesc organizațional. Vom aborda istoria, dimensionalitatea, antecedentele, consecințele şi implicațiile pentru practică ale conceptului de performanță contextuală, prin prisma unei analize critice a literaturii de specialitate. Concluziile acestei treceri în revistă susțin însemnătatea comportamentului cetățenesc pentru organizațiile contemporane, iar tendințele actuale susțin că importanța acestuia va creşte în viitor. Încurajăm cercetătorii ca în studiile viitoare asupra performanței contextuale să abordeze problematica şi în alte culturi decât Statele Unite.
\end{abstract}

Cuvinte cheie: performanța contextuală, comportament cetățenesc organizațional, performanța în muncă, psihologie industrial-organizațională.

\section{Introduction}

Job performance is probably the most important variable in industrial and organizational psychology and is sometimes referred to as the criterion or as the "the ultimate dependent variable" (Organ \& Paine, 1999). Early research on job performance has focused on task performance (e.g., identifying the tasks and their importance and frequency). Task performance can be defined as the proficiency with which the tasks are performed. However, in the past 20 years or so, considerable research has been devoted to another class of job performance that falls outside the domain of task performance: contextual or citizenship performance. In this

\footnotetext{
${ }^{1}$ Adresa de corespondență: dispas@gmail.com
}

paper, we'll present the concept of citizenship performance, a short history of the concept, we'll briefly review some of the research findings (antecedents and consequences), and provide a critical analysis with a focus on future research directions.

\section{Definition of citizenship performance}

Citizenship performance is defined as "activities (that) support the organizational, social, and psychological environment in which the technical core must function" (Borman \& Motowidlo, 1993, p. 73). Citizenship performance differs from task performance in three ways (Borman \& Motowidlo, 1993): task behaviors vary across jobs, whereas contextual behaviors are similar across jobs; 
task behaviors are more likely to be formally expected as a job requirement than contextual behaviors (which usually go above and beyond the call of duty); and the antecedents of task performance are more likely to involve cognitive ability, whereas the antecedents of citizenship performance are more likely to be dispositional or personality related.

\section{A brief history and the dimensionality of citizenship performance}

Trying to explain the relatively low correlation between satisfaction and performance, Organ (1977) suggested that the reason might be that performance had been defined too narrowly. Based on early work by Barnard (1938) and Katz \& Kahn (1966), Organ and colleagues (Bateman \& Organ, 1983; Smith, Organ, \& Near, 1983) proposed a construct called organizational citizenship behavior initially defined as discretionary behavior that goes beyond one's official role and is intended to help other people in the organization or to show support and conscientiousness toward the organization.

Building on an earlier model of soldier effectiveness (Borman, Motowidlo, Rose, \& Hanser, 1985), early literature on organizational citizenship behavior (OCB; Organ, 1988) and prosocial organizational behavior (Brief \& Motowidlo, 1986), Borman \& Motowidlo (1993) proposed a theory of work performance and made the distinction between task and contextual performance.

In their review of the organizational citizenship literature, Podsakoff, MacKenzie, Paine, and Bachrach (2000) identified 30 potential kinds of citizenship performance but they note that there is a great deal of overlap between many of these constructs. Organ \& Paine (1999) describe the distinction between citizenship performance directed at individuals and citizenship performance directed at the organization as the most consistent and interpretable distinction in the citizenship literature.

In an effort to summarize and parsimoniously integrate all the concepts proposed in the literature, Coleman \& Borman (2000) generated a set of 27 unique performance dimensions and asked a group of industrial and organizational psychologists to sort them into categories based on conceptual similarity. Using exploratory factor analysis and multidimensional scaling they found three broad dimensions, each with several subdimensions (Borman, 2004, Borman et al., 2001, Coleman \& Borman, 2000). Their findings are presented in Table 1. They note however, that the model lacks more assertive, challenging elements of citizenship participation such as Civic Virtue (Graham, 2000) - also called Advocacy Participation (Van Dyne et al., 1994). They also note that there probably is no "best" configuration for the citizenship domain, and the models should be chosen based on purposes and applications. An in-depth review of the history of the concept is beyond the scope of this article, the interested reader should refer to Borman \& Motowidlo (1993), Organ, Podsakoff, \&MacKenzie (2006) and Podsakoff et al. (2000).

\section{Antecedents of citizenship performance}

Most of the research conducted on citizenship performance has been aimed at identifying its antecedents. We can divide the antecedents of citizenship performance into four separate categories: situational, attitudinal / affective, dispositional, and motivational.

The situational antecedents can be divided into organizational factors and job characteristics. Some of the situational factors are: organizational justice (the perceived fairness of interactions between individuals and the organization), leader behavior (the quality of the relationship), and organizational culture (e.g., organizational politics). The characteristics of the jobs themselves may inhibit or encourage citizenship performance. Although only a few studies have examined the relationship between citizenship performance and job characteristics, the results of reviews (e.g., Podsakoff et al., 1996) suggest that jobs providing greater autonomy, feedback, and task variety may encourage more employee citizenship performance. 
Table 1. Dimensions and subdimensions of citizenship performance

(1) Personal support:

(2) Organizational support:
Helping - helping others by offering suggestions, showing them how to do the work and how to accomplish different tasks, providing emotional support.

Cooperating - accepting suggestions, informing them of events they should know about, putting team objectives above personal interests.

Courtesy - showing consideration, courtesy, and tact in relations with others.

Motivating - motivating others by applauding their achievement and success, showing confidence in their abilities.

Representing - representing the organization favorably to outsiders by defending it when it's criticized and by promoting its positive attributes.

Loyalty - showing loyalty by staying with the organization despite temporary hardships and by tolerating occasional difficulties, supporting the organization's mission and objectives.

Compliance - complying with reasonable organizational rules and procedures, and suggesting improvements.

(3) Conscientious initiative

Initiative - taking the initiative to do all that is necessary to accomplish objectives even if not normally part of own duties and finding additional productive work to perform when own duties are completed

Self development - developing own knowledge and skills by taking advantage of opportunities within the organization and outside the organization, using own time and resources, when necessary.

Job satisfaction and organizational commitment have also been considered as potential antecedents of citizenship performance. Results of meta-analyses (Organ \& Ryan, 1995, LePine et al., 2002) suggest a positive correlation between satisfaction and citizenship performance and also between commitment and citizenship performance (population correlations corrected for unreliability of .24 and .20).

The dispositional antecedents of citizenship performance have been widely investigated (Borman et al., 2001). The personality constructs that show the strongest correlations with citizenship performance are conscientiousness (one of the "big five" traits) and two constructs that measure the "prosocial personality orientation" (Penner et al., 1995): other-orientated empathy and helpfulness (Borman et al., 2001).

More recently, researchers tried to predict citizenship performance by understanding and identifying the role of individuals' motives for engaging in this behavior. A promising line of research by Penner and his colleagues (e.g., Penner et al., 1997; Rioux \& Penner, 2001) tries to identify the motives for citizenship performance using a functionalist approach (Snyder, 1993). Rioux \& Penner (2001) developed a scale to measure people's motives for engaging in citizenship performance, and found three distinct factors: organizational concern (e.g., I care what happens to this company), prosocial values (e.g., It is easy for me to be helpful), and impression management (e.g., I try to avoid looking bad in front of others). Two of the three motives showed differential relationships with dimensions of the predictors and the criteria: the organizational concern motive was most highly correlated with conscientiousness and the prosocial values motive was most strongly correlated with altruism. Also, concern for the organization was associated with citizenship performance toward the organization, and concern for other people was associated with citizenship performance directed at individual. Since very little research has been conducted in this area, we encourage future investigations, for example to understand how individual motives operate to influence behavior. Also, most of the studies have been correlational and cross-sectional; using experience sampling methodology or qualitative methods (participant-observation studies or in-depth interviews) can help us 
better understand the role of motives in citizenship performance. Examining the motives for citizenship performance may also provide an explanation for the inconsistent relationships between personality traits and citizenship performance dimensions: different personality traits may be relevant in different situations, depending on the functions of citizenship behaviors and on the motives for engaging in citizenship behaviors.

\section{Critical analysis of citizenship performance research}

An area of research that has received little attention from researchers is the negative consequences of citizenship performance. Bolino, Turnley, \& Niehoff (2004) theorized that citizenship performance can lead to more role ambiguity (the employees may have a hard time distinguishing between in-role and extrarole behaviors), less accurate performance appraisals, higher levels of stress, overload, work-family conflict and conflict among employees. Bolino \& Turnley (2005) found in a sample of 98 couples that higher levels of individual initiative (a form of citizenship performance) were associated with higher levels of role overload, job stress, and workfamily conflict. As they mention, this is a crosssectional study and we don't know whether individual initiative causes employee stress and strain or the other way around. A longitudinal study or a study using experience sampling methodology could be more helpful in examining causality.

In a recent meta-analytic study, Chang, Johnson, and Yang (2007) examined the relationship between emotional strain and $\mathrm{OCB}$. They found a population correlation of .16. Although they consider emotional strain an antecedent of citizenship performance, they acknowledge that the design of most of the studies included does not allow drawing causal conclusions. It is also possible that performing citizenship behaviors can lead to experiencing more strain. This would also be consistent with the conservation of resources theory (Hobfoll, 1988, 1989). According to the conservation of resources theory, individuals seek to acquire and maintain resources (such as objects, personal characteristics, conditions and energies). Hobfoll and Freedy (1993) proposed that job demands threaten one's resources, and continued exposure to demands will result in strain in the form of emotional exhaustion. This could be a useful framework to examine the relationship between citizenship performance and strain.

Most of the research on contextual performance has used a social exchange framework (Zellars \& Tepper, 2003). Based on the norm of reciprocity (Gouldner, 1960), social exchange theory posits that the employees and the organizations engage in relationships (social exchanges) outside the formal contracts that exist between them. Zellars and Tepper (2003) criticize this overreliance on social exchange theory. They argue that by focusing on social exchange theory "the amount of variance explained has remained constant", i.e. there is little improvement in the amount of variance by the various proposed predictors of citizenship performance. They outline several new possible antecedents of citizenship performance: self-efficacy, the opportunity to perform, egoistic motivations (impression management and coping with work stress) and identity management. Researchers have begun to empirically examine the proposed predictors. For example, Bolino et al. (2006) found that supervisor focused impression management tactics (self-reported by the employee) are associated with citizenship performance (supervisor ratings). Their finding has important implications for the choice of the rating source for citizenship performance: it appears that supervisor reports may not be the best source due to the likelihood of being impacted by the employees' impression management. We encourage more research on the proposed antecedents, especially using longitudinal and experimental designs.

Another are in need of more research is the measurement of citizenship performance. A variety of measures have been proposed and used in the literature (Podsakoff et al., 2000). A more careful inspection of some of the items suggests that for some measures, items that are supposed to measure citizenship performance are in fact items measuring the employees' not engaging in counterproductive work behaviors (CWB), called "antithetical items" (Dalal, 2005). This may have implications for the relationship between citizenship performance and other variables. For example, Dalal (2005) found that the relationship between citizenship performance and CWB is strong only when the measures include antithetical items.

Very little research has examined actual interventions designed to increase citizenship performance among employees. 
The only attempts we are aware of have been made by Skarlicki and Latham (1996, 1997). They trained managers in the principles of organizational justice and found that improving fairness perceptions leads to increased levels of citizenship performance. More research is needed, and other organizational interventions should be examined (e.g., increasing participation in decision making).

\section{Consequences and implications for practice}

Citizenship performance also has important consequences and implications for practice. For example, research has shown that managers do consider citizenship performance when rating employee performance (Johnson, 2001; Werner, 1994). There is also empirical evidence that citizenship performance is related to the effectiveness of the organization (for a review see chapter 7 of Organ, Podsakoff, \& MacKenzie, 2006). Some of the reasons that citizenship performance might influence organizational effectiveness are (Borman, 2004; Organ, Podsakoff, \& MacKenzie, 2006): it may enhance coworker and managerial productivity, it may help coordinate activities, it may help the organization's ability to attract and retain employees and it may increase the stability of organizational performance. However, there is a need for further research in this area in order to clarify the direction of causality, to identify potential moderators, and to better understand the mechanism through which citizenship performance influences organizational performance. Citizenship performance also has implications for personnel selection: if citizenship performance is related to organizational effectiveness than we might select job candidates based on their predisposition to engage in citizenship performance. Research shows that, for the most part, personality tends to predict citizenship performance better than task performance, and thus using personality measures to select people may have some merit. The relationship between citizenship performance and overall performance and between personality and citizenship performance may also have an impact on the interpretation of the Barrick and Mount (1991) meta-analysis (Borman, 2004). They found a moderate correlation between conscientiousness and job performance (mostly ratings of overall performance) which may reflect primarily a relation between conscientiousness and citizenship performance.

\section{Conclusions}

The empirical evidence suggests that citizenship performance is important for contemporary organizations. Most of the research on citizenship performance has occurred in the past 15 years or so. Four contemporary trends suggest that the three dimensions of citizenship performance are likely to be important in the future:

1. organizational support and conscientious initiative will become more important as global competition continues to raise the effort level required by organizational members,

2. the personal support component will be needed as the number of team based organizations increases.

3. conscientious initiative will be needed to make adaptability and willingness to exhibit extra effort more critical as downsizing continues.

4. all three dimensions will be more important as customer service and client satisfaction are increasingly emphasized.

Also, as is the case with most areas of industrial and organizational psychology, we need more research done in cultures beyond the US. There have been some studies that suggest that citizenship performance may have different structure and meaning in other cultures. For example, Turnipseed \& Murkison (2000) found different factor structures of an OCB scale in Romania and US. Work by Farh and colleagues (Farh, Early, \& Lin, 1997; Farh, Zhong, \& Organ, 2004) in China has uncovered two dimensions of citizenship performance not found in US studies: interpersonal harmony and social welfare participation. Paine \& Organ (2000) proposed that two of Hofstede's (1980) dimensions of culture are linked to citizenship performance: individualism-collectivism and power distance. Another possible cultural framework for examining differences in citizenship performance is the nine dimensions of culture found by researchers form the GLOBE project (House et al., 2004). We encourage more research using non-US samples and going beyond simply examining the dimensionality of citizenship performance to identify possible culture specific antecedents and moderators. 


\section{Further readings}

Borman, W.C., \& Motowidlo, S.J. (1993). Expending the criterion domain to include elements of contextual performance. In N. Schmitt \& W. C. Borman (Eds.), Personnel selection (pp. 71-98). San Francisco: Jossey-Bass.

Hanson, M.A., \& Borman, W.C. (2006). Citizenship performance: An integrative review and motivational analysis. In W. Benett, Jr., C. E. Lance, \& D. J. Woehr (Eds.), Performance measurement (pp. 141-173). Mahwah, NJ: Lawrence Erlbaum Associates, Inc.

LePine, J.A., Erez, A., \& Johnson, D.E. (2002). The nature and dimensionality of organizational citizenship behavior: A critical review and meta-analysis. Journal of Applied Psychology, 87, 52-65.

Organ, D.W., Podsakoff, P.M., \& MacKenzie, S.B. (2006). Organizational citizenship behavior: Its nature, antecedents, and consequences. Thousand Oaks, CA: Sage Publications, Inc.

Penney, L.M. \& Borman, W.C. (2005). The prediction of contextual performance. In A. Evers, O. Voskuijl, \& N. Anderson (Eds.), Blackwell handbook of personnel selection (pp. 376-398). Blackwell Publishers

\section{References}

Barnard, C.I. (1938). The functions of the executive. Cambridge, MA: Harvard University Press.

Bateman, T.S., \& Organ, D.W. (1983). Job satisfaction and the good soldier: the relationship between affect and employee "citizenship". Academy of Management Journal, 26, 587-595.

Bolino, M.C., \& Turnley, W.H. (2005). The personal costs of citizenship behavior: The relationship between individual initiative and role overload, job stress, and work-family conflict. Journal of Applied Psychology, 90, 740-748.

Bolino, M.C., Turnley, W.H., \& Niehoff, B.P. (2004). The other side of the story: Reexamining prevailing assumptions about organizational citizenship behavior. Human Resource Management Review, 14, 229-246.

Bolino, M.C., Varela, J.A., Bande, B., \& Turnley, W.H. (2006). The impact of impression management tactics on supervisor ratings of organizational citizenship behaviors. Journal of Organizational Behavior, 27, 281-297.

Borman, W.C. (2004). The concept of organizational citizenship. Current Directions in Psychological Science, 13, 238-241.
Borman, W.C., Motowidlo, S.J., Rose, S.R., \& Hanser, L.M. (1985). Development of a model of soldier effectiveness. Institute Report nr. 95. PDRI: Minneapolis.

Borman, W.C., Penner, L.A., Allen, T.D., \& Motowidlo, S.J. (2001). Personality predictors of citizenship performance. International Journal of Selection and Assessment, 9, 5269.

Brief, A.P., \& Motowidlo, S.J. (1986). Prosocial organizational behaviors. Academy of Management Review, 11, 711-725.

Chang, C.-H., Johnson, R.E., \& Yang, L. (2007). Emotional strain and organizational

citizenship behaviors: A meta-analytic review. Work \& Stress, 21, 312-332.

Coleman, V.I., \& Borman, W.C. (2000). Investigating the underlying structure of the citizenship performance domain. Human Resource Management Review, 10, 25-44.

Dalal, R.S. (2005). A meta-analysis of the relationship between organizational citizenship behavior and counterproductive work behavior. Journal of Applied Psychology, 90, 1241-1255.

Farh, J.L., Early, P.C., \& Lin, S.C. (1997). Impetus for action: A cultural analysis of justice and organizational citizenship behavior in Chinese society. Administrative Science Quarterly, 42, 421-444.

Farh, J.L., Zhong, C.B., \& Organ, D.W. (2004). Organizational citizenship behavior in the People's Republic of China. Organization Science, 15, 241- 253.

Graham, J.W. (2000). Promoting civic virtue organizational citizenship behavior: Contemporary questions rooted in classical quandaries from political philosophy. Human Resource Management Review, 10, 61-77.

Hobfoll, S.E. (1988). The ecology of stress. Washington, DC: Hemisphere.

Hobfoll, S.E. (1989). Conservation of resources: A new attempt at conceptualizing stress. American Psychologist, 44, 513-524.

Hobfoll, S.E., \& Freedy, J. (1993). Conservation of resources: A general stress theory applied to burnout. In W.B. Schaufeli, C. Maslach, \& T. Marek (Eds.), Professional burnout: Recent developments in theory and research (pp. 115-129). Washington, DC: Taylor \& Francis.

Hofstede, G. (1980). Culture's consequences: International differences in work-related values. Newbury Park, CA: Sage.

House, R.J., Hanges, P.J., Javidan, M., Dorfman, P.W.,\& Gupta, V. (Eds.). (2004). Culture, leadership, and organizations: The GLOBE 
study of 62 societies. Thousand Oaks, CA: Sage.

Johnson, J.W. (2001). The relative importance of task and contextual performance dimensions to supervisor judgments of overall performance. Journal of Applied Psychology, 86, 984-996.

Katz, D., \& Kahn, R.L. (1966). The social psychology of organizations. New York: Wiley.

Organ, D.W. (1977). A reappraisal and reinterpretation of the satisfaction-causesperformance hypothesis. Academy of Management Review, 2, 46-53.

Organ, D.W. (1988). Organizational citizenship behavior: The good soldier syndrome. Lenxington, MA: Lenxington.

Organ, D.W. (1997). Organizational citizenship behavior: It's construct clean-up time. Human Performance , 10, 85-97.

Organ, D., \& McFall, J. (2004). Personality and Citizenship Behavior in Organizations. In B. Schneider and D.B. Smith (Eds.), Personality and organizations (pp. 291-314). Mahwah, NJ: Lawrence Erlbaum Associates, Inc.

Organ, D.W., \& Paine, J.B. (1999). A new kind of performance for industrial and organizational psychology: Recent contributions to the study of organizational citizenship behavior. International Review of Industrial and Organizational Psychology, 14, 337-368.

Organ, D.W., \& Ryan, K. (1995). A meta-analytic review of attitudinal and dispositional predictors of organizational citizenship behavior. Personnel Psychology, 48, 775802.

Penner, L.A., Fritzsche, B.A., Craiger, J.P., \& Freifeld, T.R. (1995). Measuring the prosocial personality. In J. Butcher \& C. D. Spielberger (Eds.), Advances in personality assessment (Vol. 10, pp. 147-163). Hillsdale, NJ: Lawrence Erlbaum Associates, Inc.

Penner, L.A., Midili, A.R., \& Kegelmeyer, J. (1997). Beyond job attitudes: A personality and social psychology perspective on the causes of organizational citizenship performance. Human Performance, 10, 111-131.

Podsakoff, P.M., MacKenzie, S.B., \& Bommer, W.H. (1996). Meta-analysis of the relationship between Kerr and Jermier's substitutes for leadership and employee job attitudes, role perceptions, and performance. Journal of Applied Psychology, 81, 380-399.

Podsakoff, P.M., MacKenzie, S.B., Paine, J.B., \& Bachrach, D.G. (2000). Organizational citizenship behavior: A critical review of the theoretical and empirical literature and suggestions for future research. Journal of Management, 26, 513-563.

Rioux, S.M., \& Penner, L.A. (2001). The causes of organizational citizenship behavior: A motivational analysis. Journal of Applied Psychology, 86, 1306-1314.

Skarlicki, D.P., \& Latham, G.P. (1996). Increasing citizenship behavior within a public sector union: A test of organizational justice theory. Journal of Applied Psychology, 81, 161-169.

Skarlicki, D.P., \& Latham, G.P. (1997). Leadership training in organizational justice to increase citizenship behavior within a labor union: A replication. Personnel Psychology, 50, 617634.

Smith, C.A., Organ, D.W., \& Near, J.P. (1983). Organizational citizenship behavior: Its nature and antecedents. Journal of Applied Psychology, 68, 653-663.

Snyder, M. (1993). Basic research and practice problems: The promise of a "functional" personality and social psychology. Personality and Social Psychology Bulletin, 19, 251-264.

Turnipseed, D.L., \& Murkison, E. (2000). A bicultural comparison of organizational citizenship behavior: Does the OCB phenomenon transcend national culture? The International Journal of Organizational Analysis, 8, 200- 222.

Van Dyne, L.V., Graham, J.M., \& Dienesch, R.M. (1994). Organizational citizenship behavior: Construct redefinition, measurement and validation. Academy of Management Journal, 37, 765-802.

Werner, J.M. (1994). Dimensions that make a difference: Examining the impact of in-role and extra-role behaviors on supervisory ratings. Journal of Applied Psychology, 79, 98-107.

Zellars, K.L., \& Tepper, B.J. (2003). Beyond social exchange: New directions for organizational citizenship theory and research. Research in Personnel and Human Resources Management, 22, 395-424.

Author's note: This paper is based on material presented in Borman (2004), Hanson \& Borman (2006), and Penney \& Borman (2005). 